\title{
Life-cycle patterns in the design and adoption of default funds in DC pension plans*
}

\author{
JOACHIM INKMANN AND ZHEN SHI \\ Department of Finance, University of Melbourne, Level 12, 198 Berkeley Street, Victoria 3010, \\ Australia and Netspar \\ (e-mail: jinkmann@unimelb.edu.au, zshi@unimelb.edu.au)
}

\begin{abstract}
We argue that we should see a negative relationship between the share of risky assets in the default fund of a defined contribution (DC) pension plan and the average plan member age if trustees design the default fund in line with predictions from the life-cycle portfolio choice theory. Adoption of the default fund should be low in DC plans with high member age dispersion if default funds are indeed designed for the average plan member and members become aware of this. From analyzing a panel dataset of Australian DC pension plans, we obtain results that are consistent with both hypotheses.
\end{abstract}

JEL CODES: G11, G23, G28

Keywords: Pension plan, default fund, defined contribution, life-cycle portfolio choice.

\section{Introduction}

According to the Superannuation Legislation Amendment (MySuper Core Provisions) Bill, contributions on behalf of Australian defined contribution (DC) pension plans members, who do not actively choose a portfolio from a menu of investment options offered by the pension plan, need to be directed into an approved default fund, a so-called MySuper product, since January 1, 2014. Apart from balanced funds, life-cycle investment products like target-date funds may qualify as a MySuper product. The Bill resembles the Pension Protection Act 2006 in the USA that prescribes balanced funds or life-cycle investment funds as Qualified Default Investment Alternatives (QDIAs). ${ }^{1}$ Similar to the US experience, January

\footnotetext{
* Part of this project was conducted while the authors were visiting the Labor \& Population division at RAND Corporation in Santa Monica, CA. We thank Arie Kapteyn and the division's staff for their hospitality. We are grateful to APRA (the Australian Prudential Regulation Authority) for making available the pension plan data used in this paper. We thank two anonymous referees, Kevin Davis, Katja Hanewald, Michael Hurd, Theo Nijman, Øyvind Norli, James Smith, Sabine Wende, and participants in presentations at RAND, University of Melbourne, La Trobe University, the 2013 Annual Meeting of the American Risk and Insurance Association, the 21st Annual Colloquium of Superannuation Researchers, and the 1st CEPAR International Conference for helpful comments.

1 According to the Pension Protection Act, plan sponsors are exempt from their fiduciary liability in relation to potential losses from the default investment strategy if the plan offers a QDIA.
} 
2014 data reveal that a significant fraction of Australian DC plans started offering life-cycle default funds as a result of the new legislation. ${ }^{2}$ Like in the USA, life-cycle default funds basically did not exist before the policy intervention. ${ }^{3}$

In this paper, we investigate whether the observed allocation of DC pension plan assets in the pre-intervention period in Australia is consistent with insights from lifecycle portfolio choice theory. ${ }^{4}$ This topic is relevant beyond the Australian case for many countries that have implemented pension systems in which individuals have to decide on the allocation of their pension assets. We use Australian pre-intervention data to test whether the age structure of plan members affects the design and adoption of default funds. More specifically, we first test whether the share of risky assets in the default fund declines with the average age of plan members (design hypothesis). We then test whether the share of plan assets invested in the default fund declines with the age dispersion among plan members (adoption hypothesis). The design hypothesis is related to the main insight from life-cycle portfolio choice theory: the share of wealth invested in risky assets should decline over the working life of individuals (Cocco et al., 2005). In the absence of dedicated life-cycle products, trustees are likely to refer to the average plan member age when aiming to design a default fund in line with predictions from life-cycle portfolio choice theory. The adoption hypothesis is related to Choi et al. (2003) who observe that it is much easier to design optimal default options for a homogeneous group of pension plan participants. Thus, pension plan members are more likely to opt out of the default fund when age dispersion is high if the default fund is indeed designed with the average plan member age in mind.

Although we are not aware of any test of the adoption hypothesis in previous literature, the design hypothesis has been tested in a recent paper by Bikker et al. (2012). The authors provide evidence that trustees of defined benefit (DB) and hybrid pension plans in the Netherlands reduce the share of risky assets in the strategic asset allocation when the average age of active plan members increases. ${ }^{5}$ This result is somewhat surprising because DB pension assets should be allocated to match the liabilities of DB pension plans. ${ }^{6}$ The life-cycle portfolio choice theory was designed

2 According to Mercer (2014), about 20\% of MySuper products approved by January 2014 were of a lifecycle investment type. Among retail plans, the corresponding figure was 52\%. Similarly, as of 2008, 47\% of 401(k) plans with Vanguard recordkeeping in the U.S. designated a QDIA; $85 \%$ of these plans nominated a life-cycle investment fund (Vanguard, 2009).

3 However, Australian pre-intervention default funds were considerably riskier than U.S. pre-intervention default funds. Basu and Drew (2010) show that the average default fund in Australia in 2008 was balanced with $67 \%$ in stocks. We provide a much more detailed analysis below. Byrne et al. (2007) report similar figures for the UK. In stark contrast, Choi et al. document that $66 \%$ of automatic enrollment companies in the USA had a stable value or money market default fund in 2001.

4 See Cocco et al. (2005), Gomes et al. (2008), Viceira (2009), and Poterba et al. (2009) for an introduction to life-cycle portfolio choice models and products.

5 Similar results were obtained by Alestalo and Puttonen (2006) and Gerber and Weber (2007) for Finnish and Swiss DB pension plans, respectively.

6 See Sharpe and Tint (1990), Hoevenaars et al. (2008), Van Binsbergen and Brandt (2009), and Inkmann et al. (2014). The liability of a DB pension plan depends on the age structure of plan members as well, which determines the maturity of the pension liability. In this sense, DB plans with older plan members are more likely to be invested in assets with shorter maturity and vice versa. Dutch DB pension plans are required to adjust contributions and indexation of accrued benefits in response to variations of the funding ratio, which may affect the asset allocation independent of any life-cycle or liability-matching investment considerations. 
for asset allocation decisions of households and is therefore much more suitable as a template for investment decisions in DC pension plans, which are the focus of our paper. As a robustness check, we revisit Bikker et al. (2012) and also test the design hypothesis on a sample of Australian DB and hybrid pension plans. ${ }^{7}$

Based on a dataset of Australian DC pension plans regulated by the Australian Prudential Regulation Authority (APRA) and observed over the period 2004-2012, we obtain results that are consistent with the design and adoption hypotheses. The average plan member age profile of the share of risky assets in the default fund shows an exemplary life-cycle investment pattern, in line with normative results obtained by Cocco et al. (2005) in the presence of background risk. After controlling for other covariates, the share of risky assets in the default fund declines from about $77 \%$ in young pension plans with an average plan member age of 30 years to about $23 \%$ in mature plans with an average member age of 65 years. This result turns out to be robust against changes in the definition of the class of risky assets. Moreover, adoption of the default fund declines from about $67 \%$ in homogeneous pension plans with a low member age dispersion of 8 years to about $22 \%$ in heterogeneous plans with a high age dispersion of 22 years. Both effects turn out to be highly statistically significant. Thus, trustees seem to take into account the average age of plan members when designing the default fund and members seem to be aware of this and tend to opt out of the default fund when age dispersion is high. As expected, the average plan member age is insignificant for the design of the strategic asset allocation of Australian DB and hybrid pension plans.

We interpret our results as empirical evidence for life-cycle behavior among trustees and members of Australian DC pension plans. In discussing our results we will point out limitations of our data source and refer to a number of alternative explanations of our findings that are unrelated to life-cycle investment concerns. In particular, we will show that our results may be partly attributed to retail plans, which deliberately nominate default funds consisting of cash only in order to provide incentives for customers to seek investment advice. Nevertheless, our results suggest that the increasing use of life-cycle products in default funds in post-intervention Australia is likely to have a moderate impact on the aggregate allocation of DC pension plan assets.

Our paper is related to an extensive literature in economics and finance, which provides evidence that 401(k) DC pension plan members tend to follow paths of least resistance when faced with retirement savings decisions (Choi et al., 2002). Plan members tend to rely on heuristics, or rules of thumb, which may result in savings outcomes that are difficult to rationalize (Benartzi and Thaler, 2007). For example, plan members may adopt naive diversification strategies like the $1 / n$-heuristic (Benartzi, 2001; Huberman and Jiang, 2006), or underdiversify by accumulating large portfolio shares of employer (Benartzi, 2001; Mitchell and Utkus, 2004b) or domestic stocks (French and Poterba, 1991). Benartzi and Thaler (2002) show that members may even prefer the median asset allocation of their peers to their own allocation.

7 Unlike Bikker et al. (2012) who base their empirical analysis on a cross-section of pension plans, we use a panel dataset of pension plans observed over 9 years. 
Moreover, savings decisions seem to be seriously affected by the way these decisions are framed, ranging from the number of available investment options (Cronqvist and Thaler, 2004; Sethi-Iyengar et al., 2004; Iyengar and Kamenica, 2010), and the share of investment options in a particular asset class (Brown et al., 2007), over the presentation of historical returns (Benartzi and Thaler, 1999), to allegedly minor details such as the number of lines available on the form for selecting investment funds (Benartzi and Thaler, 2007). Particularly well documented is the power of default options in influencing plan members' participation, contribution and asset allocation decisions. ${ }^{8}$ Regarding the latter, Madrian and Shea (2001), Agnew et al. (2003) and Choi et al. (2004b) show that $401(\mathrm{k})$ pension plan members tend to adopt the default fund even if it consists of an undiversified investment in a money market fund or employer stock (Choi et al., 2009).

Why are default options so powerful in directing savings decisions? Beshears et al. (2009) discuss a number of potential explanations: plan members may want to avoid the complexity of making non-default decisions by adopting the default option, in particular when they are not well prepared to evaluate a possibly large number of investment alternatives. Evidence for this hypothesis is given by Agnew and Szykman (2005) who show that financially less literate investors are more likely to adopt a default fund. Procrastination, possibly caused by time-inconsistent preferences, may be another explanation for a status-quo bias and the power of default options. Plan members affected by such a problem of self-control may never reallocate their portfolios away from the default fund even when the associated transaction costs are small. Based on household survey data, Van Rooij and Teppa (2014) conclude that financially literate individuals are more likely to opt out defaults in economic decisionmaking while procrastination favors defaults in non-economic decision-making. Plan members also may perceive the default fund as an endorsement, a form of implicit investment advice offered by their employer. The endowment effect may be another explanation for the power of default options (Madrian and Shea, 2001): Once enrolled in the default fund, plan members may value the default more than they would have had, were they not enrolled in the default fund, because they develop aversion against losses caused by deviations from the default strategy.

Financial education at the workplace and sophisticated pension plan design (Choi et al., 2004a; Mitchell and Utkus, 2004a) has been proposed to improve savings outcomes of plan members. Although the success of financial education appears to be limited, ${ }^{9}$ pension plan design has been shown to have a potentially enormous impact on savings outcomes. Exploiting the power of default options, any policy that encourages trustees of DC pension plans to design default funds in line with normative models of portfolio choice, is likely to improve asset allocation outcomes. With its emphasis on portfolio choice decisions of households, the life-cycle portfolio choice

8 Buetler and Teppa (2007) show that default options are also highly influential for the decision to annuitize retirement wealth.

9 For example, while $47 \%$ of seminar attendees planned to change their fund selection at the conclusion of a financial education seminar, only $15 \%$ actually changed their fund selection subsequently, not much more than the $10 \%$ of non-attendees who changed their fund selection during the same period (Choi et al., 2002). One has to bear in mind the small size of the intervention when interpreting these findings. 
theory can provide a benchmark for a desired asset allocation outcome. The aforementioned Australian and US policy interventions are examples of such a libertarian paternalistic approach (Thaler and Sunstein, 2003) to the regulation of default funds. ${ }^{10}$

\section{Institutional background and data}

\subsection{Institutional background}

The current landscape of occupational pension plan arrangements in Australia was shaped in September 1985 when trade unions negotiated a 3\% employer contribution - a so-called superannuation or super - to be paid into approved superannuation funds ${ }^{11}$ on behalf of the employees covered by the industry agreement. ${ }^{12}$ From this point on, DC pension plans started to replace traditional DB pension plans in Australia. Superannuation became mandatory for all employers with the introduction of the superannuation guarantee system on July 1, $1992 .{ }^{13}$ The initial 3\% minimum guarantee was slowly increased over time until it reached its current level of $9.5 \%$ on July 1, 2014. Employees may voluntarily contribute an additional percentage of their salary and receive a tax benefit when doing so. ${ }^{14}$ The majority of pension plans are of the DC type, followed by a minority of hybrid plans and a small number of DB plans. Since July 1, 2005, employees are generally able to nominate a pension plan of their choice and to request a transfer of their savings accumulated in different plans to the chosen plan. ${ }^{15}$ Pension plans are offered on the company and industry levels, by the public sector and as for-profit retail products. ${ }^{16}$ Retail products are divided by most observers into corporate master trusts (CMTs) and personal superannuation products. Although CMTs often operate as a workplace default pension plan similar to industry plans, personal superannuation products are usually directly sold to retail customers through financial advice channels.

Members of DC plans are typically offered a menu of investment options. The pension plan nominates a default fund in which members are automatically enrolled until they choose to opt out and select different funds from the menu of investment options. Before the Australian Superannuation Legislation Amendment Bill 2011 came into effect on July 1, 2013, the design of the default fund had to satisfy prudential

10 The 2002 reform of the Chilean pension system, in which all members are enrolled by default in a lifecycle fund (Berstein et al., 2013), is another example.

11 Deviating from the terms used in the USA, pension plans are called superannuation funds in Australia. These should not be confused with mutual funds. DC pension plans are called accumulation funds in Australia. We usually will use the more familiar US terms.

12 See APRA (2007) for details on the history of Australian occupational pension plans.

13 Exempt from this guarantee are employees earning less than AUD 450 per month, part-time employees under 18 years and employees aged 70 or over. Note that AUD $1=$ USD $0.94=$ EUR 0.69 as of July 1 , 2014.

14 Annual contributions below AUD 30,000 receive a tax benefit. A higher limit of AUD 35,000 applies to those aged 49 years or over. Any excess contributions are currently taxed at $46.5 \%$.

15 Analyzing Australian data from 2004, Fry et al. (2007) document that about 19\% of respondents were 'fairly likely' or 'very likely' to change their pension plans within the next 2 years.

16 In addition, small groups of less than five employees can choose to have a Self-Managed Superannuation Fund (SMSF) regulated by the Australian Taxation Office. 
standards. ${ }^{17}$ As a result of this policy intervention, pension plans have been obligated to direct default contributions into a MySuper compliant, balanced or life-cycle (target-date) default fund since January 1, 2014. ${ }^{18}$

Because all employees are covered by mandatory superannuation at a current rate of $9.5 \%$ ( $9 \%$ during our sample period), the asset allocation decision of Australian pension plans members provides a rather complete summary of their expected savings outcome. This is unlike the USA, where savings outcomes may be significantly compromised by non-participation in pension plans or enrollment with total contribution rates that are too low by any standard of savings adequacy. ${ }^{19}$

\subsection{Data}

Our empirical analysis is based on a panel dataset of all pension plans with more than four members regulated by APRA over the period 2004-2012. ${ }^{20}$ The data are constructed from questionnaires these pension plans are obligated to submit to APRA on an annual basis under the Financial Sector (Collection of Data) Act 2001. The number of pension plans in the data steadily declines from 1,245 plans in 2004 to 298 plans in 2012 as a result of plan mergers, which are usually initiated by the trustees of smaller corporate pension plans who decide to transfer members' accounts to larger industry and retail plans (Cummings, 2012). ${ }^{21}$ The raw data include 4,870 planyear observations. We remove 3,419 plan-year observations because of incomplete information that may arise because of confidentiality concerns or privacy laws. We will show below that the selected sample remains highly representative in terms of pension assets. We also exclude 184 observations of DC pension plans that do not offer investment choice because the adoption hypothesis becomes meaningless in this case. The resulting sample consists of 1,267 plan-year observations that can be divided into 827 DC and 440 DB and hybrid ${ }^{22}$ observations. We will use the latter subsample for a robustness check below. Table 1 shows the sample decomposition by observation period.

Summary statistics for all variables used in our empirical analysis are also given in Table 1. Although our raw dataset includes all Australian pension plans with at least

17 Fiduciary duties in Australia and the USA are in general similar: In Australia, 'the trustee's duties and powers are performed and exercised in the best interests of beneficiaries' (Section 52 of the Superannuation Industry (Supervision) Act 1993 (SIS)). In the USA, 'a fiduciary shall discharge his duties with respect to a plan solely in the interest of the participants and beneficiaries' (paragraph 404(a)(1) (B) of the Employee Retirement Income Security Act (ERISA)).

18 Muir (2012) points out that the obligation of an Australian plan sponsor with respect to the default fund is limited to the choice of a MySuper product. The financial supervisor bears responsibility for approving the MySuper product while its provider serves as a responsible fiduciary in monitoring the MySuper product. Muir (2012) differentiates this Australian 'financial services-based model' of fiduciary obligation from the US 'employer-based model' in which the plan sponsor ultimately remains responsible as a fiduciary for the selection and monitoring of investment options including QDIAs, even if these tasks are delegated to investment advisors.

19 Along these lines, Madrian and Shea (2001) find that a plan design change from opt-in to opt-out (autoenrollment) substantially increased the participation in a $401(\mathrm{k})$ plan, but the savings outcome was compromised by a low default contribution rate of $3 \%$ and a money market default fund.

20 The data are available from http://www.apra.gov.au

21 This can be explained by the finding that the expenses of managing pension plans in Australia (as well as in the USA) rise less than proportionately with size (Bateman and Mitchell, 2004).

22 Hybrid plans combine members with DC and DB pension arrangements. 
Table 1. Summary statistics

\begin{tabular}{|c|c|c|c|c|}
\hline & Mean & Std. dev. & Min. & Max. \\
\hline \multicolumn{5}{|l|}{ Defined contribution pension plans } \\
\hline Average plan member age/100 & 0.44 & 0.08 & 0.30 & 0.64 \\
\hline Member age dispersion/100 & 0.14 & 0.03 & 0.07 & 0.22 \\
\hline Member age/100 skewness & 0.81 & 0.39 & -0.32 & 3.12 \\
\hline Number of plan members $/ 100$ & 1045 & 1722 & 3.44 & 12715 \\
\hline Share of retirees & 0.07 & 0.11 & 0.00 & 0.68 \\
\hline Employer contribution share & 0.66 & 0.28 & 0.06 & 0.99 \\
\hline Plan assets in billion dollars & 2.82 & 5.15 & 0.02 & 43.15 \\
\hline Log plan assets per member in 1000 dollars & 3.35 & 1.02 & 0.09 & 5.68 \\
\hline No. of investment options/100 & 1.14 & 3.15 & 0.02 & 28.29 \\
\hline Log no. of investment options & 3.12 & 1.60 & 0.69 & 7.95 \\
\hline Plan on public offer & 0.88 & 0.33 & 0.00 & 1.00 \\
\hline Retail pension plan & 0.64 & 0.48 & 0.00 & 1.00 \\
\hline Corporate pension plan & 0.01 & 0.11 & 0.00 & 1.00 \\
\hline Industry/public pension plan & 0.35 & 0.48 & 0.00 & 1.00 \\
\hline Share of risky assets in default fund & 0.58 & 0.27 & 0.00 & 1.00 \\
\hline Share of plan assets in default fund & 0.47 & 0.36 & 0.00 & 1.00 \\
\hline \multicolumn{5}{|l|}{ Defined benefit and hybrid pension plans } \\
\hline Average member age/100 & $0.42 * * *$ & 0.05 & 0.32 & 0.63 \\
\hline Member age dispersion/100 & $0.13 * * *$ & 0.02 & 0.05 & 0.22 \\
\hline Member age/100 skewness & 0.77 & 0.32 & -1.00 & 1.84 \\
\hline Number of plan members $/ 100$ & $2103 * * *$ & 4795 & 2.13 & 28589 \\
\hline Share of retirees & $0.04 * * *$ & 0.06 & 0.00 & 0.39 \\
\hline Employer contribution share & $0.80 * * *$ & 0.21 & 0.05 & 1.00 \\
\hline Plan assets in billion dollars & $6.29 * * *$ & 9.61 & 0.00 & 52.10 \\
\hline Log plan assets per member in 1000 dollars & $4.17 * * *$ & 0.89 & -2.56 & 6.10 \\
\hline Plan on public offer & $0.41 * * *$ & 0.49 & 0.00 & 1.00 \\
\hline Retail pension plan & $0.19^{* * *}$ & 0.39 & 0.00 & 1.00 \\
\hline
\end{tabular}


Table 1 (cont.)

\begin{tabular}{|c|c|c|c|c|c|c|c|c|c|c|}
\hline & & & & & Mean & \multicolumn{2}{|c|}{ Std. dev. } & Min. & \multicolumn{2}{|c|}{ Max. } \\
\hline \multicolumn{5}{|c|}{ Corporate pension plan } & $0.33 * * *$ & \multicolumn{2}{|l|}{0.47} & 0.00 & \multicolumn{2}{|l|}{1.00} \\
\hline \multicolumn{5}{|c|}{ Industry/public pension plan } & $0.48 * * *$ & \multicolumn{2}{|l|}{0.50} & 0.00 & \multicolumn{2}{|l|}{1.00} \\
\hline \multicolumn{5}{|c|}{ Share of risky assets in fund } & $0.70 * * *$ & \multicolumn{2}{|l|}{0.12} & 0.00 & \multicolumn{2}{|l|}{1.00} \\
\hline Observations & 2004 & 2005 & 2006 & 2007 & 2008 & 2009 & 2010 & 2011 & 2012 & All \\
\hline $\mathrm{DC}$ & 87 & 106 & 94 & 89 & 99 & 101 & 93 & 80 & 78 & 827 \\
\hline DB/hybrid & 32 & 41 & 45 & 50 & 52 & 55 & 59 & 54 & 52 & 440 \\
\hline Total & 119 & 147 & 139 & 139 & 151 & 156 & 152 & 134 & 130 & 1267 \\
\hline
\end{tabular}

Notes: The table shows summary statistics for the subsamples of defined contribution and defined benefit/hybrid pension plans, respectively. The ${ }^{* * *}$, ${ }^{* * *}$ superscripts denote significance at the 1,5 , and 10 percent significance levels, respectively, for a two-sample $t$-test of the equality of means in the two subsamples. 
Table 2. Pension plan assets by sector in 2012

\begin{tabular}{lcccc}
\hline \hline & $\begin{array}{c}\text { DC plan } \\
\text { sample }\end{array}$ & $\begin{array}{c}\text { DB/hybrid plan } \\
\text { sample }\end{array}$ & $\begin{array}{c}\text { Total } \\
\text { sample }\end{array}$ & $\begin{array}{c}\text { Population } \\
\text { (APRA) }\end{array}$ \\
\hline Retail (\%) & 61.3 & 33.0 & 43.8 & 40.5 \\
Corporate (\%) & 0.1 & 9.0 & 5.6 & 6.1 \\
Industry (\%) & 35.0 & 33.1 & 33.8 & 29.2 \\
Public (\%) & 3.5 & 24.8 & 16.7 & 24.3 \\
Total share (\%) & 100.0 & 100.0 & 100.0 & 100.0 \\
Total assets & 296.6 & 484.1 & 780.7 & 833.7 \\
(billion \$) & & & & \\
\hline \hline
\end{tabular}

Notes: The table shows in columns 2-4 the distribution of pension assets in DC plans, DB/hybrid plans, and all plans across the different sectors of pension plans regulated by APRA in the data. The last column shows the distribution of total pension assets in the population (source: APRA, 2012). The sample covers $93.64 \%$ of the total 2012 pension assets in the population.

five plan members, Table 1 shows that the smallest DC pension plan in our final sample has 344 members, whereas the smallest DB or hybrid pension plan has 213 members. This is the result of the aforementioned incomplete information problem. The average plan size in terms of membership is 104,500 for DC plans and 210,300 for DB and hybrid plans. The average age of members in DC and DB/hybrid pension plans is 44 and 42 years, respectively. The age dispersion among plan members - measured as the standard deviation of age - in DC and DB/hybrid pension plans is 14 and 13 years, respectively.

While we need to exclude 3,603 observations, the final sample remains highly representative of the universe of Australian DC pension plans as Table 2 shows. The DC pension plans in our final sample account for $93.64 \%$ of the total pension assets in the magnitude of $\$ 833.7$ billion $^{23}$ regulated by APRA in 2012. Moreover, the distribution of pension assets across the retail, corporate, industry and public sectors in our final sample is very similar to the corresponding distribution in the underlying population. For this reason, we are confident that we can rule out potential sample selection issues.

Table 2 also shows that in terms of assets, for-profit retail plans are dominating among DC pension plans with a share of $61.3 \%$ of total assets in 2012. Industry plans account for $35 \%$ of total DC pension plan assets, while the public and corporate sectors account for $3.5 \%$ and $0.1 \%$, respectively. The distribution of total assets in DB and hybrid pension plans across sectors is very different from the distribution of DC pension plan assets. Retail and industry plans each account for about one-third of the total assets, public pension plans for about one-fourth and corporate plans for about $9 \%$ of the total assets in 2012. 

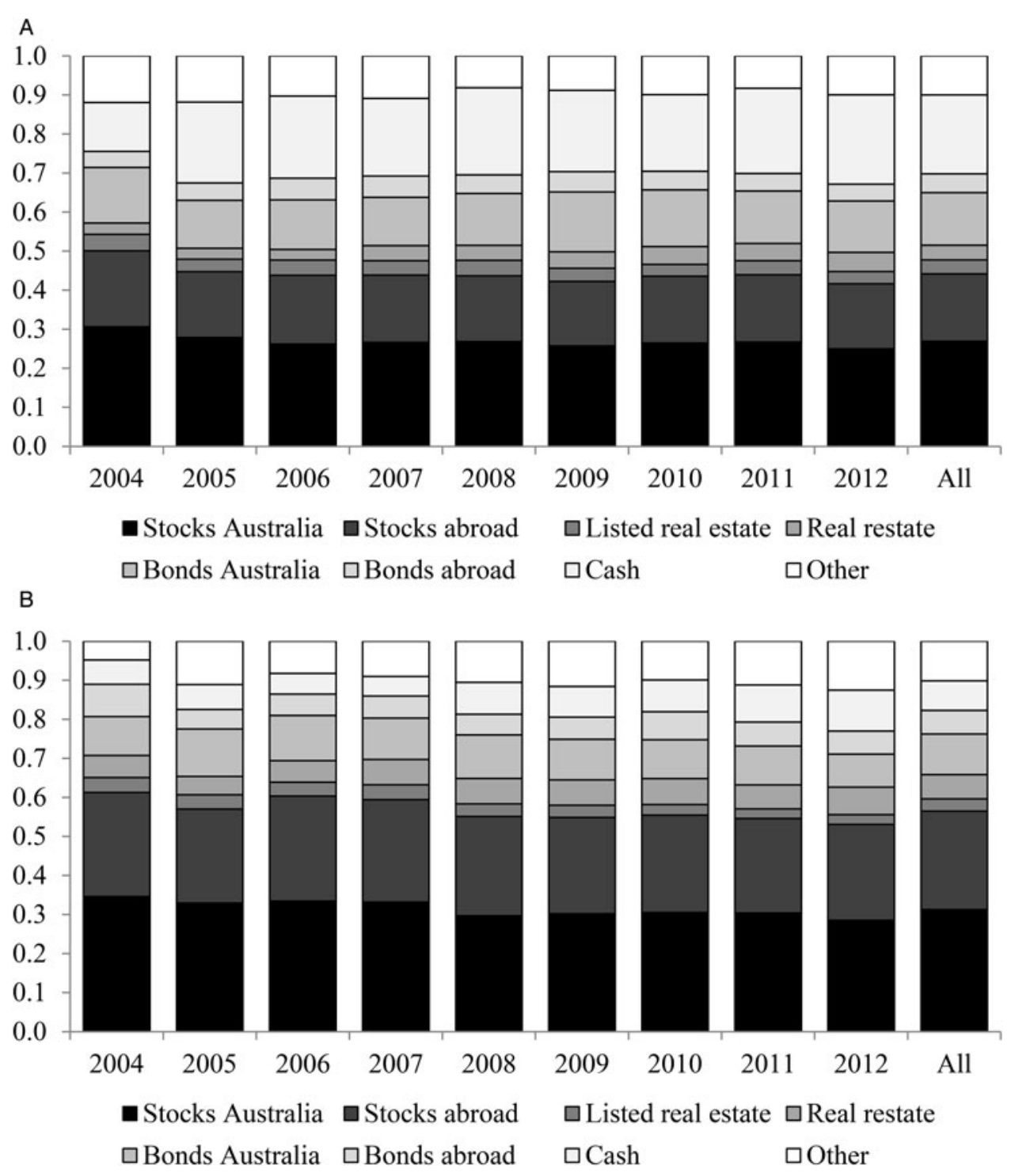

Figure 1. Asset allocation in DC and DB/hybrid pension plans. (A) Average default asset allocation in DC pension plans, 2004-2012. (B) Average asset allocation in DB and hybrid pension plans, 2004-2012.

Notes: The graph in panel (A) shows the average default asset allocation in DC pension plans over the period 2004-2012. The graph in panel (B) shows the average asset allocation in DB and hybrid pension plans over the same period. The bar titled 'All' refers to the time series average.

\section{Empirical analysis}

\subsection{Default fund summary statistics}

Panel (A) of Figure 1 shows average default asset allocations in the data by observation period. The data distinguish eight asset classes: Australian and international 
stocks, listed and physical real estate, Australian and international bonds, cash and 'other assets'. The average default fund chosen by the trustees of DC pension plans over the period 2004-2012 includes 26.9\% Australian stocks and 17.3\% international stocks. Listed and physical real estate each receive an average allocation of about $3.7 \% .13 .5 \%$ of plan assets are invested by default in Australian bonds and $4.8 \%$ in international bonds. The average investment in cash is $20.2 \%$ while 'other assets' receive an allocation of $10 \%$. The composition of default funds remains fairly stable throughout the sample period. In particular, there seems to be no impact of the 2008 global financial crisis on the design of the average default fund.

It is interesting to compare the average default asset allocation chosen by DC plans with the average strategic asset allocation implemented by the trustees of DB and hybrid pension plans over the 2004-2012 period. According to panel (B) of Figure 1, the latter plans have a substantially higher allocation of plan assets to stocks: on average, $31.3 \%$ of assets are allocated to Australian stocks and another $25.2 \%$ to international stocks. About 3.1\% are invested in listed real estate and $6.2 \%$ in physical real estate. Australian bonds receive an average allocation of $10.4 \%$, whereas international bonds account for $6 \%$ of the portfolio. The average investments in cash and 'other assets' are $7.6 \%$ and $10 \%$, respectively. Hence, in the observation period, the average default fund of DC pension plans is more conservative than the average asset allocation of DB plans. The latter is again fairly stable throughout the observation period with the exception of a notable reduction in stocks in the average portfolio since 2008, which is most likely a direct consequence of the global financial crisis in 2008 .

In the following, we will focus on the share of risky assets in the default fund (also called the default share of risky assets from now on). We do this in order to compare our findings with the life-cycle portfolio choice literature, which generally only distinguishes between a risky and a riskless asset. We choose to classify stocks, listed real estate, and 'other assets' as risky, while bonds, physical real state, and cash and are assumed to be less risky. We include 'other assets' among the risky assets because this category includes relatively illiquid investments in infrastructure, private equity, and hedge funds (Cummings and Ellis, 2011). We will perform a number of robustness checks below in which we redefine the class of risky assets.

Panel (A) of Figure 2 shows box plots for the distribution of the default share of risky assets across the observation period. The box plots are characterized by relatively large interquartile ranges, which reflect considerable variation in the default share of risky assets among DC plans. The median value is well above the average in all years due to a substantial number of plans, which choose a default fund that consists of riskless assets only. With the exception of 2012, we also observe DC plans in all years, which choose to invest all assets by default in risky asset classes.

Again, we compare these results with the share of risky assets in the strategic asset allocation of DB and hybrid pension plans. The box plots in panel (B) of Figure 2 reveal substantially less variation in the share of risky assets among these plans compared to DC plans. The interquartile range is very narrow in all years. There is a striking reduction in the minimum allocation to risky assets between 2007 and the years since 2008. Although the minimum allocation to risky assets was $45.4 \%$ in 2007 , it has been $0 \%$ since then. This is almost certainly a response to the 2008 global financial crisis. 


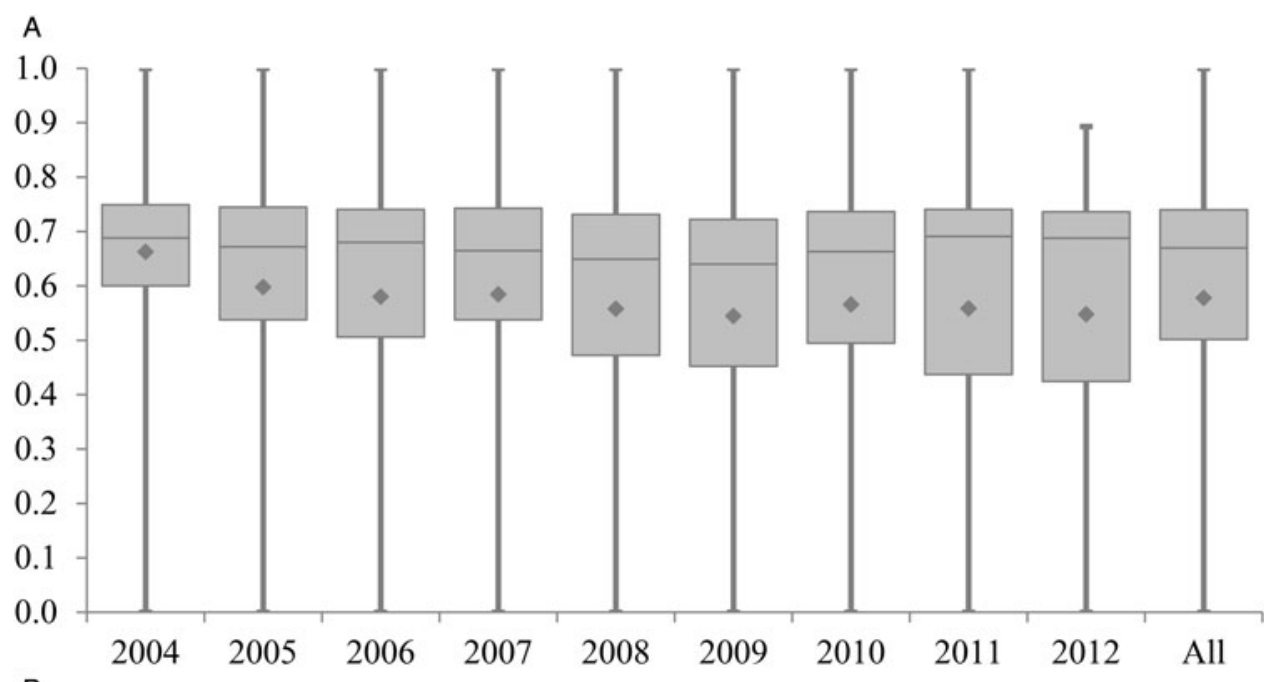

B

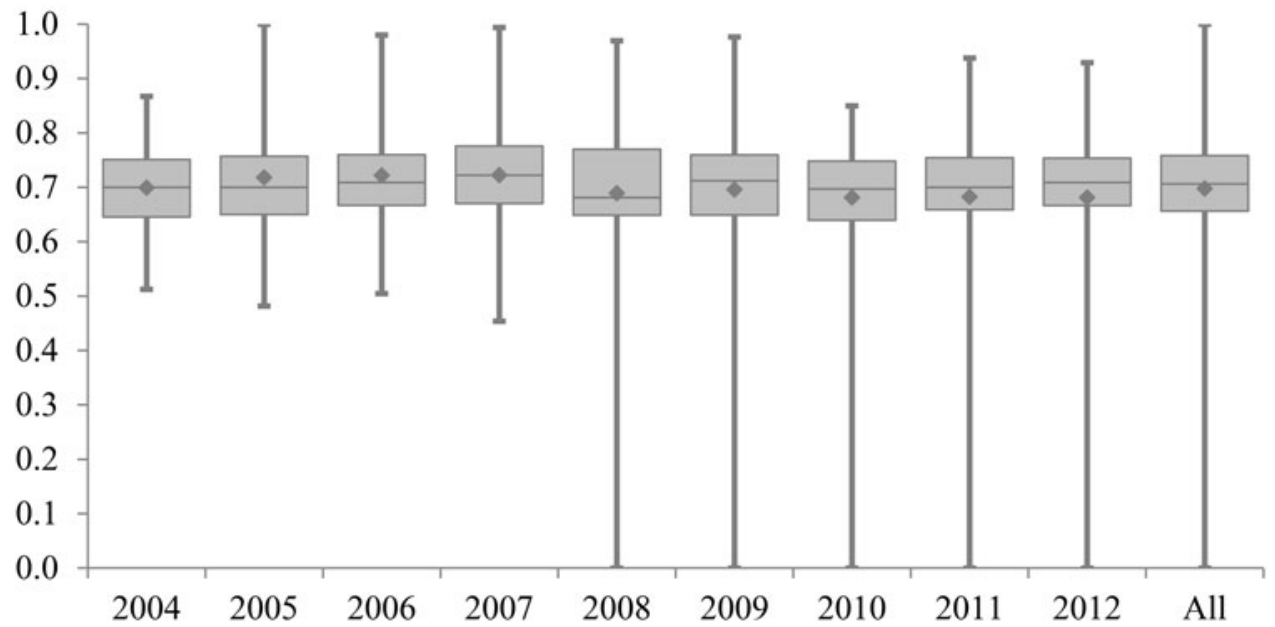

Figure 2. Box plots of the allocation to risky assets in DC and DB/hybrid pension plans. (A) Default allocation to risky assets in DC pension plans, 2004-2012. (B) Allocation to risky assets in DB and hybrid pension plans, 2004-2012.

Notes: Box plots are shown for the share of risky assets in the default asset allocation of DC pension plans (panel A) and the asset allocation of $\mathrm{DB} /$ hybrid pension plans (panel B). The boxes depict the interquartile range between the first and third quartile of the share of risky assets in each year. The horizontal line within each box depicts the median value, the diamond the mean value. The box titled 'All' refers to the pooled time series.

\subsection{Testing the design hypothesis}

Probably the most robust finding of the life-cycle portfolio choice literature is a negative relationship between the share of wealth invested in stocks and age. ${ }^{24}$ This is

24 One exception is the life-cycle model by Benzoni et al. (2007), which implies an increasing allocation to risky assets over the life cycle. However, De Jong (2012) shows that this result can be attributed to a unique risk factor driving both stock returns and dividend growth. 
because human capital is decreasing over a household's life cycle. Therefore the need to compensate relatively low risk human capital with investments in risky assets decreases with age. We should find evidence for a negative relationship between the default share of risky assets and the average plan member age in our pre-intervention data if trustees adhere to elements of life-cycle investing when designing the default fund in the absence of dedicated life-cycle portfolio choice products.

Our goal in this section is to produce average plan member age profiles of the default share of risky assets that are comparable to the age profiles of risky assets produced by the life-cycle portfolio choice literature (e.g., Cocco et al., 2005). We have seen in the previous subsection that the default share of risky assets varies between $0 \%$ and $100 \%$ in our data. We employ two-limit tobit models (Maddala, 1983) instead of linear models for the regression analysis below in order to avoid predicted age profiles outside the $[0,100] \%$ range. ${ }^{25}$ In the tables below, we present average partial effects (APEs) estimated from the two-limit tobit model, which quantify the sample average of the marginal impact of an explanatory variable on the conditional mean of the left-hand-side variable, and their estimated standard errors. ${ }^{26}$

We test the design hypothesis by estimating regression (1) in Table 3 using our sample of DC pension plans observed from 2004-2012. The dependent variable is the default share of risky assets. A 1 year increase in the average age of DC pension plan members reduces the default share of risky assets by 1.6 percentage points. This relationship is statistically highly significant at the $1 \%$ level. The estimated coefficient is also highly significant from an economic point of view. Panel (A) in Figure 3 plots the estimated average plan member age profile of the default share of risky assets $^{27}$ while controlling for all other covariates in Table 3, which we will discuss below. ${ }^{28}$ The default share of risky assets declines from about $77 \%$ in young pension plans with an average member age of 30 years to about $23 \%$ in a mature pension plan with an average member age of 65 years. ${ }^{29}$ For comparison, the calibrated life-cycle portfolio choice model of Cocco et al. (2005) predicts an age-profile in the benchmark case for high school graduates without a bequest motive that is shifted upwards by about 20 percentage points. When the authors increase the background risk by introducing a riskier labor income process or a positive probability of unemployment, they generate predicted age profiles that are very similar to the one in panel (A) in Figure 3.

25 As usual, we assume a normal distribution with unrestricted support conditional on a vector of explanatory variables for the latent variable underlying the tobit specification. In the current context, this means that default shares outside the $[0,100] \%$ interval could be realized in the absence of regulatory constraints by shorting either risky or risk-free assets.

26 See the Appendix for the technical details.

27 The profile is obtained from calculating the sample average of equation (A.2) in the appendix for a given range of average plan member age from 25 to 70 years. The individual predictions for all DC plans, obtained from evaluating equation (A.2) at each plan's respective average member age, are scattered around the average member age profile.

28 To see the relationship between this graph and the APE of average member age given in column (2) of Table 3, note that the weighted average of the member age-specific effects of an additional year is equal to the APE (of size -1.6037), when the weights reflect the number of plans observed with each member age.

29 The predicted average member age profile is roughly consistent with the life-cycle investment rule of thumb frequently advocated by professional financial planners to invest $100-$ age percent of wealth in stocks (Ameriks and Zeldes, 2004). 
Table 3. ML estimates of two-limit tobit models

(1)

\begin{tabular}{|c|c|c|c|c|}
\hline \multirow[b]{2}{*}{ Dependent variable } & \multicolumn{2}{|c|}{ RISKY } & \multicolumn{2}{|c|}{ INVEST } \\
\hline & Estimate & Std. error & Estimate & Std. error \\
\hline Intercept & $1.5026^{* * *}$ & 0.1782 & $1.2743^{* * *}$ & 0.1575 \\
\hline Average plan member age & $-1.6037 * * *$ & 0.3332 & 0.1752 & 0.2954 \\
\hline Member age dispersion & $-1.6913 * * *$ & 0.5584 & $-3.2762 * * *$ & 0.4845 \\
\hline Member age skewness & -0.0217 & 0.0401 & -0.0536 & 0.0355 \\
\hline Share of retirees & -0.1860 & 0.1563 & $0.3206^{* * *}$ & 0.1373 \\
\hline Employer contribution share & $-0.2360 * * *$ & 0.0573 & $-0.2679 * * *$ & 0.0501 \\
\hline Log plan assets per member & $0.0633^{* * *}$ & 0.0168 & $-0.0675^{* * *}$ & 0.0148 \\
\hline Log no. of investment options & $-0.0375^{* * *}$ & 0.0072 & $-0.0533 * * *$ & 0.0062 \\
\hline Plan on public offer & $0.0498 *$ & 0.0300 & -0.0355 & 0.0268 \\
\hline Corporate pension plan & 0.0772 & 0.0767 & -0.0713 & 0.0685 \\
\hline Industry/public pension plan & $0.0991 * * *$ & 0.0268 & $0.2605^{* * *}$ & 0.0231 \\
\hline$\sigma_{u}$ & $0.2698 * * *$ & 0.0076 & $0.2569 * * *$ & 0.0064 \\
\hline Year dummies & Yes & & Yes & \\
\hline Number of observations & 827 & & 827 & \\
\hline
\end{tabular}

Notes: The table shows estimated average partial effects (APEs) from two-limit tobit models. The dependent variable is either the share of risky assets in the default fund (RISKY) or the share of plan assets invested in the default fund (INVEST). The sample consists of DC pension plans observed over the period 2004-2012. The estimated standard errors are based on the sandwich ML covariance matrix estimator. The ${ }^{* * *},{ }^{* *},{ }^{*}$ superscripts denote significance at the $1 \%$, $5 \%$ and $10 \%$ significance levels, respectively. $\sigma_{u}$ is the standard deviation of the residual.

Our findings are therefore at least qualitatively consistent with the design hypothesis, which states that trustees of DC pension plans are guided by principles of life-cycle investing when designing the default fund.

The predicted average plan member age-profile takes into account the covariates in column (1) of Table 3 that we add to control for observed pension plan heterogeneity. There are a number of interesting findings regarding the impact of these covariates on the default share of risky assets. We find a negative and significant impact of plan member age dispersion on the share of risky assets in the default fund. A one standard deviation (14 years) increase in age dispersion reduces the default share of risky assets by 24 percentage points. One interpretation of this finding could be that trustees design a more conservative default fund if plan members are heterogeneous in order to prevent members with high background risk from excessive risk-taking. The impact of the skewness of the member age distribution on the default share of risky assets is insignificant.

The share of total annual contributions contributed by employers to the pension plan is negatively related to the default share of risky assets. A one standard deviation increase in the share of employer contributions significantly reduces the default share of risky assets by 6.33 percentage points. Assuming that employees reduce their voluntary contributions to the pension plan when they are liquidity constrained, which 

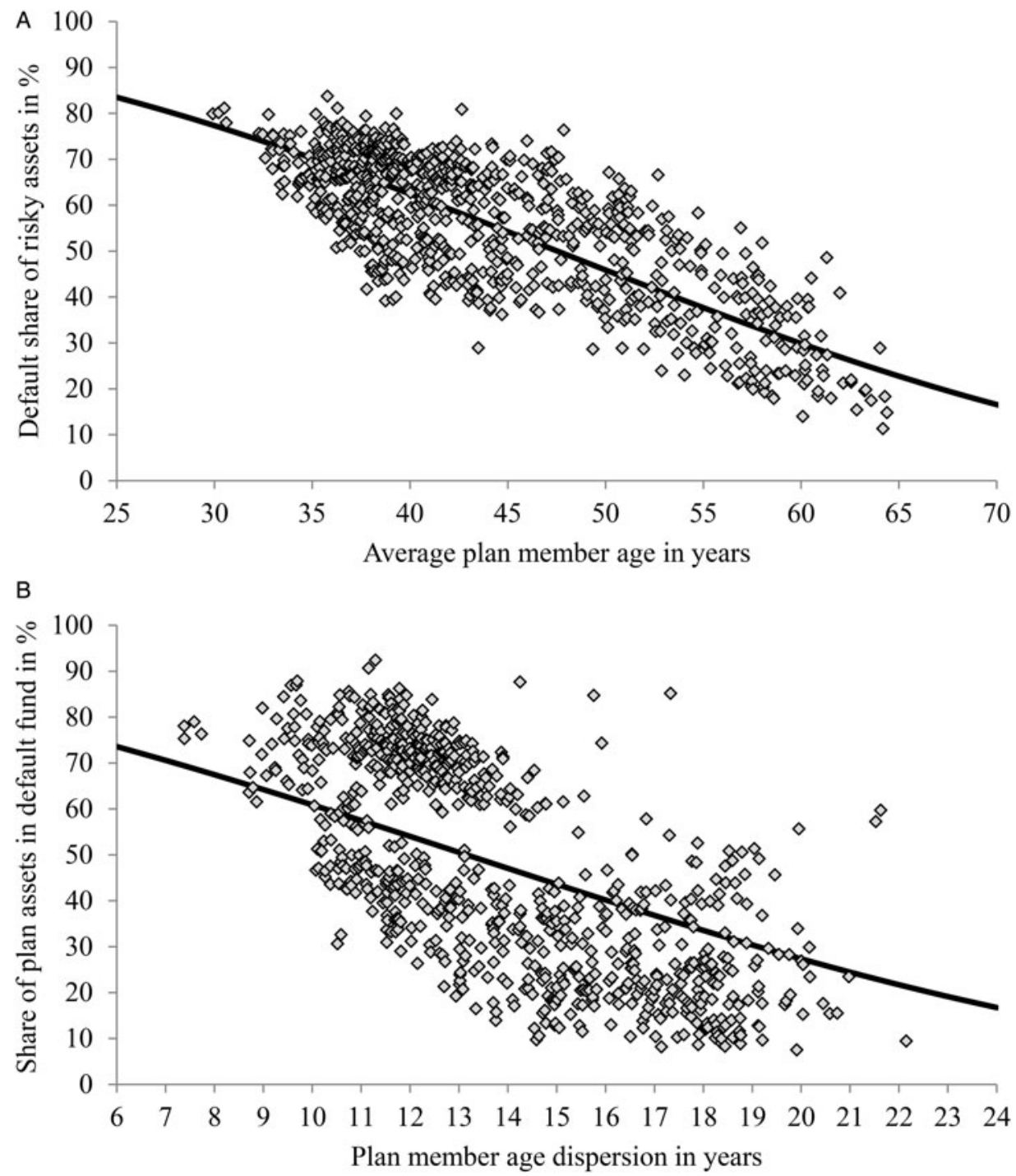

Figure 3. Predictions from the two-limit tobit model. (A) Share of risky assets in the default fund (RISKY, Table 3, column (1)). (B) Share of plan assets invested in the default fund (INVEST, Table 3, column (2)).

Notes: The black line in panel (A) depicts sample averages of the conditional expectation of the share of risky assets in the default fund (RISKY) evaluated at a range of average DC plan member ages from 25 to 70 years. The black line in panel (B) depicts sample averages of the conditional expectation of the share of plan assets invested the default fund (INVEST) evaluated at a range of DC plan member age dispersions from 6 to 24 years. The two graphs were obtained from evaluating sample averages of the mean function (A.2) in the Appendix at the estimates presented in Table 3. The squares show the predicted values of RISKY and INVEST in panels (A) and (B), respectively, for the underlying sample of DC plans. 
would result in an increase of the employer contribution share, the reduction in the default share of risky assets could reflect a lower demand for stocks from liquidityconstrained plan members.

We find a positive and significant impact of the average pension assets per member on the default share of risky assets. A $\$ 100,000$ increase in the average pension plan assets per member increases the default share of risky assets by 5.7 percentage points. ${ }^{30}$ This could reflect a higher risk-bearing capacity of wealthy plan members. ${ }^{31}$ Increasing the number of options by 100 (the standard deviation is 315 ), reduces the default share of risky assets by about 3.75 percentage points. The effect is statistically highly significant. Again, this could be interpreted in line with protecting procrastinating plan members with high background risk from excessive risk-taking, assuming there are investment options available that allow for higher risk exposure.

Finally, we find a statistically and economically highly significant impact of the sector in which the pension plan is operating. Compared to the benchmark retail sector, plans in the industry or public sector on average allocate an additional 9.9 percentage points of the default fund to risky assets. ${ }^{32}$ This result is not surprising because the self-employed who are likely to face higher levels of background risk than employees can be found among the members of retail plans. The corporate sector dummy turns out to be insignificant.

\subsection{Testing the adoption hypothesis}

We have seen that the average age profile of the default share of risky assets resembles one typically generated from life-cycle portfolio choice models. If the default fund is designed to reflect the risk appetite of a member with average age, younger, and older members who follow the principles of life-cycle investing should rationally opt out of the default fund. Thus, adoption of the default fund should decrease with age dispersion. In the following, we provide a test of this adoption hypothesis. We measure adoption as the share of total plan assets invested in the default fund.

We test the adoption hypothesis by estimating regression (2) in Table 3 using our sample of DC pension plans observed from 2004 to 2012. The dependent variable is the share of total plan assets invested in the default fund. Table 1 shows that on average $47 \%$ of plan assets are invested in the default fund. The average varies between $43.9 \%$ in 2009 and $50.2 \%$ in 2010 in the sample period. Adoption of the default fund ranges between $0 \%$ and $100 \%$ in our data. For this reason, we again estimate two-limit tobit models in this section and provide APEs and their standard errors in Table 3.

Member age dispersion has a negative and statistically significant impact on the adoption of the default fund. A one standard deviation (3 years) increase in member age dispersion reduces adoption of the default fund by 9.83 percentage points. Panel

30 Recall that in a semi-log model where an explanatory variable (with coefficient $\beta$ ) has been transformed by the log transformation, the dependent variable changes by $\beta / 100$ units for a one unit change in the explanatory variable.

31 However, we do not observe the plan members' aggregate wealth outside the pension plan.

32 Ellis et al. (2008) provide earlier evidence that Australian retail pension plans tend to choose more conservative default funds than the trustees of not-for-profit pension plans. 
(B) in Figure 3 plots the predicted member age dispersion profile of adoption. On average, adoption of the default fund is about $67 \%$ in DC pension plans with a homogeneous age structure ( 8 years standard deviation of member age). Adoption decreases to about $22 \%$ in plans with a heterogeneous age structure ( 22 years standard deviation). The difference is economically highly significant. This finding is consistent with the adoption hypothesis, which states that adoption of the default fund should decrease with age dispersion. In line with the argument of Choi et al. (2003), defaults tend to be optimal for a homogeneous group of plan members. Plan members who realize that the default fund is designed for a member of average age, rationally opt out of the default fund when age dispersion is high.

The predicted member age dispersion profile of adoption conditions on a number of covariates in Table 3 that is included to control for observed plan heterogeneity. Among these covariates, the average member age turns out to be insignificant for the adoption of the default fund. This is in line with our expectation because the actual average age should not matter when the default fund is designed for a member of average age. The impact of the skewness of the member age distribution on the adoption of the default fund turns out to be insignificant as well.

A one standard deviation (11 percentage points) increase in the share of retirees ${ }^{33}$ among plan members increases adoption of the default fund by 3.5 percentage points. The effect is statistically significant. Since we already control for the first three moments of plan member age in our regressions, this finding is unrelated to the member age distribution. One explanation for our result could be that plan members tend to procrastinate more during retirement when pension assets are decumulated, than during working life when pension assets are accumulated. ${ }^{34}$

The share of total annual contributions paid by employers to the pension plan is negatively related to the adoption of the default fund. A one standard deviation (28 percentage points) increase in the share of employer contributions significantly reduces adoption of the default fund by 7.5 percentage points. Continuing with our earlier interpretation of the share of employer contributions as an indicator for the presence of liquidity-constrained plan members, this result may suggest that these plan members opt out of the default fund to switch to less risky funds.

A $\$ 100,000$ increase in the average pension plan assets per member decreases adoption of the default fund by 6.75 percentage points. The effect is statistically highly significant. This is in line with expectations if we assume that higher levels of financial wealth are positively correlated with financial literacy. Agnew and Szykman (2005) show that financially literate investors are less likely to adopt the default fund.

Statistically most significant is the effect of investment choice. According to Table 1, DC plans in our data offer between 2 and 2,829 investment options. We find an estimated APE of -0.053 for the log number of investment options in column (2) of Table 3, reflecting a 5.3 percentage point decrease in the adoption of the default fund when the number of investment options increases by 100. Our results suggest

33 Defined as members in the pension payout phase, which is not necessarily identical to retirement because of transition to retirement arrangements.

34 Related to this, Agarwal et al. (2009) find that individuals make the best financial decisions around age $45-50$, 'the age of reason'. 
that investment choice induces plan members to opt out of the default fund. Cronqvist and Thaler (2004), Sethi-Iyengar et al. (2004), and Iyengar and Kamenica (2010) find evidence that large choice sets can lead to choice overload and a preference for simple options. Our results are more in line with Papke (2003) who finds that plan members with investment choice are significantly more likely to make annual contributions, another form of an active decision.

The adoption of the default fund within industry and public pension plans is about 26 percentage points higher than the adoption of the default fund in retail plans. The effect is statistically and economically highly significant. There are at least two possible explanations for this finding. First, active employees who decide to opt out of a default corporate or industry pension plan to join a retail plan, may also be more likely to opt out of the default fund. Second, in contrast to retail plans, industry and public pension plans may be in a better position to design the default fund according to the needs of their particular clientele. ${ }^{35}$

\subsection{Discussion and robustness checks}

In this section, we discuss alternative explanations for our empirical results, point out data limitations and run a number of robustness checks for our test of the design hypothesis.

Our results are not only consistent with the life-cycle portfolio choice theory but also with portfolio choice models, which either assume that relative risk aversion increases with age (e.g., Morin and Suarez, 1983) or that the returns on risky assets are mean reverting (e.g., Campbell and Viceira, 2005). All three theories imply an optimal allocation to risky assets that declines over the life cycle because human capital, risk tolerance, or the investment horizon are decreasing with age. Based on portfolio choice data, it is impossible to distinguish between these theories. However, while the life-cycle portfolio choice theory has been successful in describing observed equity holdings (Gomes and Michaelides, 2005), both increasing risk aversion with age and mean reversion in stock returns have been questioned (Riley Jr. and Chow, 1992; Welch and Goyal, 2008). Predictions from life-cycle portfolio choice models also have been shown to match observed annuity and life insurance holdings (e.g., Inkmann et. al., 2011; and Inkmann and Michaelides, 2012) that are difficult to reconcile with theories of increasing risk aversion or mean reversion. For these reasons, we prefer to link our results to the life-cycle portfolio choice theory.

Our tests of the design and adoption hypotheses are compromised by a number of data limitations. Regarding our test of the adoption hypothesis, we cannot distinguish between those plan members that remain invested in the default fund because of procrastination or any other of the reasons mentioned in the introduction for the power of default options and those members who deliberately decide to stay in the default fund because it happens to be their preferred option. Also, for those plan members who decide to opt out from the default fund, we neither observe the age nor the fund to which they move their pension assets. If we had this information, we could 
test if young (old) plan members are indeed moving their pension assets into relatively high (low) risk investment options as predicted by the life-cycle portfolio choice theory. However, it seems difficult to explain the negative and significant impact of age dispersion on adoption with procrastination or any of the other aforementioned reasons for the power of defaults. Rational behavior in line with the life-cycle portfolio choice theory appears to be a significant predictor of the adoption of the default fund. From our point of view, this is an important contribution of our paper to a literature that emphasizes irrational decision-making of members in DC pension plans.

Regarding our test of the design hypothesis, we note that we do not observe any sources of background risk for the members of the pension plans included in our planlevel data. The life-cycle portfolio choice literature emphasizes the role of background risk for the determination of the optimal asset allocation across the life cycle. ${ }^{36}$ In general, higher background risks lead to less risky investments. Since we cannot observe the sources of background risk in our data, we are not able to quantitatively match the predicted age profile of the default share of risky assets with predictions from life-cycle portfolio choice models. However, qualitatively our results are in line with life-cycle models that assume some background risk.

We interpret our results for the design hypothesis as evidence that trustees design default funds in a way, which is consistent with the life-cycle portfolio choice theory. Alternatively, the result can be interpreted as individuals, potentially guided by financial advisors, selecting themselves into pension plans that offer a default fund, which fits their age and background risk. In this case, plan members would behave rationally in line with life-cycle portfolio choice theory, while trustees are not necessarily guided by this theory. We cannot distinguish between these two explanations in the data because they lead to identical outcomes. However, remaining in the default plan but opting out of the default fund in order to adjust the asset allocation appears more likely to us than switching to another plan with an appropriate default fund. The search costs in the latter case should exceed those in the former case.

Table 4 contains robustness results for the estimated APE of average plan member age from a number of alternative specifications of regression (1) in Table 3 . We repeat the results from this regression as a baseline result in the first row of Table 4. All alternative regressions include the same set of conditioning variables employed in regression (1) in Table 3. To save space, we only focus on the effect of average plan member age in our discussion of the robustness checks, which is central for our test of the design hypothesis.

In the second row of Table 4, we test the design hypothesis on a sample of $440 \mathrm{DB}$ and hybrid pension plans observed over the period 2004-2012. As mentioned earlier, we do not expect to find evidence for the design hypothesis in the strategic asset allocations implemented by DB and hybrid pension plans. This is because the strategic asset allocations of these plans should reflect asset-liability management considerations instead of life-cycle portfolio choice behavior. The estimated APE of the average plan member age is statistically insignificant, which is in line with earlier

36 For example, labor income risk (Cocco et al., 2005), house price risk (Cocco, 2004), and health risk (De Nardi et al. 2010) contribute to a household's background risk. 
Table 4. Robustness analysis - APE of Average plan member age

\begin{tabular}{lcc}
\hline \hline & Estimate & Std. error \\
\hline (1) Baseline regression (column (1) in Table 3) & $-1.6037^{* * *}$ & 0.3332 \\
(2) Defined benefit and hybrid pension plan sample & 0.1655 & 0.2799 \\
(3) Excluding retail plans with cash default funds & $-0.6437^{* * *}$ & 0.2469 \\
(4) Excluding 'others' from the definition of risky assets & $-1.3479^{* * *}$ & 0.3509 \\
(5) Adding 'physical real estate' to the definition of risky assets & $-1.5016^{* * *}$ & 0.3239 \\
(6) Adding 'international bonds' to the definition of risky assets & $-1.6374^{* * *}$ & 0.3382 \\
\hline \hline
\end{tabular}

Notes: The table shows a robustness analysis for the estimated average partial effect (APE) of 'Average plan member age' from two-limit tobit models. See the text for a detailed description. The dependent variable is the share of risky assets in the default fund (RISKY). The sample consists of either DB and hybrid (row 2) or DC (all other rows) pension plans observed over the period 2004-2012. The underlying sample size is 440 in row (2), 730 in row (3), and 827 in all other rows. The estimated standard errors are based on the sandwich ML covariance matrix estimator. The ${ }^{* * * *},{ }^{* *},{ }^{*}$ superscripts denote the significance at the $1 \%, 5 \%$, and $10 \%$ significance levels, respectively.

results for DB and hybrid pension plans in the Netherlands obtained by Bikker et al. (2012). ${ }^{37}$ Trustees of DB and hybrid plans do not take into account the age of the average plan member when designing the strategic allocation of plan assets. Indirectly, this robustness check provides further support for the design hypothesis in our sample of DC pension plans. The average plan member age effect only can be detected in the subsample in which it should be present according to life-cycle portfolio choice theory.

We cannot distinguish CMT retail plans from personal superannuation retail products in our data. The latter commonly have an 'administrative default' fund that consists of cash only (termed 'cash default fund' in the following) in order to provide incentives for customers to seek investment advice, which usually would lead to a transfer of plan assets to more balanced 'flagship' investment options. ${ }^{38}$ Our result that retail plan members are less likely to stay enrolled in the default fund is in line with such a practice. If personal retail plans attract older customers, we would find pension plans in our data that combine cash default funds with high average plan member ages. Although not intended, these plans would seem to behave in line with predictions from the life-cycle portfolio choice theory. We observe 97 retail planyear observations with cash default funds in our data. These plans indeed have members with a higher median age of 53.3 years than retail plans with non-cash default funds (44.5 years) and non-retail plans (38.4 years). For this reason, we exclude these 97 observations from the regression documented in the third row of Table 4. The estimated APE of average plan member age remains negative and significant

37 However, as mentioned earlier, these authors find a negative and significant effect of the average age of active pension plan members. We control for the share of active plan members by including the share of retirees in all regressions.

38 We thank a referee for pointing out this industry practice, which at least to our knowledge appears to be undocumented in the literature about Australian pension plans. 
but turns out to be considerably reduced in absolute value compared to our baseline regression: a 1 year increase in the average age of DC pension plan members reduces the default share of risky assets by about 0.64 percentage points (compared to 1.6 percentage points in the baseline regression). Thus, the age profile of the default share becomes flatter. However, we cannot rule out that some of the excluded observations deliberately design a cash default to serve an older clientele. Therefore, the result has to be seen as the worst-case scenario in terms of support for the life-cycle portfolio choice theory. Nevertheless, the result indicates that some retail default funds, which seem to be constructed in line with the life-cycle portfolio choice theory, may actually be designed to provide incentives that are unrelated to any life-cycle investment concerns.

Finally, we change the definition of the class of risky assets for the regressions in the remaining rows of Table 4 . Compared to the baseline definition in the first row, we exclude 'other assets' from the class of risky assets in the fourth row, and include physical real estate and international bonds, respectively, in the fifth and sixth rows. Although we know that 'other assets' include illiquid assets such as investments in infrastructure, private equity and hedge funds, we do not know whether this asset class also includes less risky investments. The inclusion of physical real estate and international bonds is motivated by the 2008 global financial crisis, which is covered by our data source. Contagion in financial markets during the subprime credit crisis is well documented (e.g., Longstaff, 2010). Although we ideally would like to distinguish assets based on their provenience and default risk for this exercise, the data do not contain such information. The results show that our baseline results are fairly robust with respect to the definition of the class of risky assets. Compared to its baseline estimate in the magnitude of -1.60 , the APE of the average plan member age turns out to be -1.35 when 'other assets' are excluded, -1.50 when physical real estate is included, and -1.64 when international bonds are added. Thus, our results for the design hypothesis are robust against changes in the definition of the endogenous variable.

\section{Conclusion}

In this paper, we investigate whether life-cycle patterns exist in the design and adoption of default funds in DC pension plans in the absence of dedicated life-cycle portfolio choice products. We argue that we should see a negative relationship between the share of risky assets in the default fund of a DC pension plan and the average plan member age if trustees design the default fund in line with predictions from the lifecycle portfolio choice model (design hypothesis). We also argue that adoption of the default fund should be low in DC plans with high member age dispersion if default funds are indeed designed for the average plan member and members become aware of this (adoption hypothesis).

We use a panel dataset of all Australian DC pension plans collected by the pension plan supervision authority over the period 2004-2012 to test the two hypotheses. The sample predates a policy intervention in 2013 that requires Australian DC pension plans to direct contributions on behalf of DC pension plans members, who do not 
actively choose a portfolio from a menu of investment options offered by the pension plan, into an approved default fund that can be of a balanced or life-cycle type. As a result of this policy intervention, life-cycle default funds, while absent from preintervention data, have become popular in Australia, in particular among retail pension plans.

Our analysis provides evidence for life-cycle patterns in the design and adoption of default funds in DC pension plans. After controlling for other covariates, the share of risky assets in the default fund declines from about $77 \%$ in young pension plans with an average plan member age of 30 years to about $23 \%$ in mature plans with an average member age of 65 years. This result turns out to be robust against changes in the definition of the class of risky assets. Moreover, adoption of the default fund declines from about $67 \%$ in homogeneous pension plans with a low member age dispersion of 8 years to about $22 \%$ in heterogeneous plans with a high age dispersion of 22 years. Both effects are highly statistically significant. Thus, trustees of DC pension plans seem to take into account the average plan member age when designing the default fund and members seem to be aware of this and tend to opt out of the default fund when age dispersion is high. As expected, we do not find any life-cycle pattern in the strategic asset allocation chosen by DB and hybrid pension plans.

We discuss alternative explanations of our findings that are unrelated to life-cycle considerations and provide arguments in favor of interpreting our results as evidence of life-cycle investment behavior. However, given the data at hand we are not able to distinguish between competing theories using formal statistical tests. We find evidence that our results may be partly driven by retail plans, which design default funds that consist of cash only in order to provide incentives for their customers to seek financial advice. Our dataset does not allow us to separate such strategic behavior from lifecycle investment concerns for an older clientele.

Occupational pension plans can play an important role in improving households' savings and investment decisions. According to our preferred interpretation, our results indicate that trustees are aware of their responsibilities when designing default funds. Since pre-intervention default funds already show patterns of life-cycle investing, we do not expect a drastic change in the aggregate allocation of DC pension plan assets as a result of the 2013 policy intervention that allows for life-cycle default funds in Australia.

\section{References}

Agarwal, S., Driscoll, J., Gabaix, X., and Laibson, D. (2009) The age of reason: financial decisions over the life cycle and implications for regulation. Brookings Papers on Economic Activity, 2009(Fall): 51-101.

Agnew, J., and Szykman, L. (2005) Asset allocation and information overload: the influence of information display, asset choice, and investor experience. Journal of Behavioral Finance, 6 (2): $57-70$.

Agnew, J., Balduzzi, P., and Sunden, A. (2003) Portfolio choice and trading in a large 401 (k) plan. American Economic Review, 93(1): 193-215.

Alestalo, N., and Puttonen, V. (2006) Asset allocation in Finnish pension funds. Journal of Pension Economics and Finance, 5(1): 27-44. 
Ameriks, J., and Zeldes, S. P. (2004) How do household portfolio shares vary with age? Working paper, Columbia University.

APRA (2007) A recent history of superannuation in Australia. In 'APRA Insight 2'.

Basu, A., and Drew, M. (2010) The appropriateness of default investment options in defined contribution plans: Australian evidence. Pacific-Basin Finance Journal, 18(3): 290-305.

Bateman, H., and Mitchell, O. (2004) New evidence on pension plan design and administrative expenses: The Australian experience. Journal of Pension Economics and Finance, 3(1): 63-76.

Benartzi, S. (2001) Excessive extrapolation and the allocation of 401(k) accounts to company stock. Journal of Finance, 56(5): 1747-1764.

Benartzi, S., and Thaler, R. (1999) Risk aversion or myopia? Choices in repeated gambles and retirement investments. Management Science, 45(3): 364-381.

Benartzi, S., and Thaler, R. (2002) How much is investor autonomy worth? Journal of Finance, 57(4): 1593-1616.

Benartzi, S., and Thaler, R. (2007) Heuristics and biases in retirement savings behavior. Journal of Economic Perspectives, 21(3): 81-104.

Benzoni, L., Collin-Dufresne, P., and Goldstein, R. S. (2007) Portfolio choice over the life-cycle when the stock and labor markets are cointegrated. Journal of Finance, 62(5): 2123-2167.

Berstein, S., Fuentes, O., and Villatoro, F. (2013) Default investment strategies in a defined contribution pension system: a pension risk model application for the Chilean case. Journal of Pension Economics and Finance, 12(4): 379-414.

Beshears, J., Choi, J., Laibson, D., and Madrian, B. (2009) The importance of default options for retirement saving outcomes: evidence from the United States. In Brown, J., Liebman, J., and Wise, D. (eds), Social Security Policy in a Changing Environment, Chicago: University of Chicago Press, pp. 167-195.

Bikker, J., Broeders, D., Hollanders, D., and Ponds, E. (2012) Pension funds' asset allocation and participant age: a test of the life-cycle model. Journal of Risk and Insurance, 79(3): 595-618.

Brown, J., Liang, N., and Weisbenner, S. (2007) Individual account investment options and portfolio choice: behavioral lessons from 401 (k) plans. Journal of Public Economics, 91 (10): 1992-2013.

Buetler, M., and Teppa, F. (2007) The choice between an annuity and a lump sum: results from Swiss pension funds. Journal of Public Economics, 91: 1944-1966.

Byrne, A., Dowd, K., Blake, D., and Cairns, A. (2007) Default funds in UK defined contribution pension plans. Financial Analysts Journal, 63(4): 40-51.

Campbell, J. Y., and Viceira, L. (2005) The term structure of the risk-return trade-off. Financial Analysts Journal, 61(1): 34-44.

Choi, J., Laibson, D., and Madrian, B. (2004a) Plan design and 401 (k) savings outcomes. National Tax Journal, 57(2): 275-298.

Choi, J., Laibson, D., and Madrian, B. (2009) Mental accounting in portfolio choice: evidence from a flypaper effect. American Economic Review, 99(5): 2085-2095.

Choi, J., Laibson, D., Madrian, B., and Metrick, A. (2002) Defined contribution pensions: plan rules, participant choices, and the path of least resistance. In Poterba, J. (ed), Tax Policy and the Economy. Cambridge: MIT Press, pp. 67-113.

Choi, J., Laibson, D., Madrian, B., and Metrick, A. (2003) Optimal defaults. American Economic Review Papers and Proceedings, 93(2): 180-185.

Choi, J., Laibson, D., Madrian, B., and Metrick, A. (2004b) For better or for worse: default effects and 401 (k) savings behavior. In Wise, D. (ed), Perspectives on the Economics of Aging. Chicago: University of Chicago Press, pp. 81-121.

Cocco, J. (2004) Portfolio choice in the presence of housing. Review of Financial Studies, 18(2): $535-567$.

Cocco, J., Gomes, F., and Maenhout, P. (2005) Consumption and portfolio choice over the life cycle. Review of Financial Studies, 18(2): 491-533. 
Cronqvist, H., and Thaler, R. (2004) Design choices in privatized social-security systems: learning from the Swedish experience. American Economic Review Papers and Proceedings, 94: 424-428.

Cummings, J. R. (2012) Effect of fund size on the performance of Australian superannuation funds. Working Paper, Australian Prudential Regulation Authority.

Cummings, J. R., and Ellis, K. (2011) Risk and return of illiquid investments: a trade-off for superannuation funds offering transferable accounts. Working Paper, Australian Prudential Regulation Authority.

De Jong, F. (2012) Portfolio implications of cointegration between labor income and dividends. De Economist, 160: 397-412.

De Nardi, M., French, E., and Shea, D. (2010) Why do the elderly save? The role of medical expenses. Journal of Political Economy, 118(1): 39-75.

Ellis, K., Tobin, A., and Tracey, B. (2008) Investment performance, asset allocation and expenses of large superannuation funds. Working Paper, Australian Prudential Regulation Authority.

French, K., and Poterba, J. (1991) Investor diversification and international equity markets. American Economic Review, 81: 222-226.

Fry, T., Heaney, R., and McKeown, W. (2007) Will investors change their superannuation fund given the choice? Accounting \& Finance, 47(2): 267-283.

Gerber, D. S., and Weber, R. (2007) Demography and investment behavior of pension funds: evidence for Switzerland. Journal of Pension Economics and Finance, 6(3): 313-337.

Gomes, F., and Michaelides, A. (2005) Optimal life-cycle asset allocation: understanding the empirical evidence. Journal of Finance, 60(2): 869-904.

Gomes, F., Kotlikoff, L., and Viceira, L. (2008) Optimal life-cycle investing with flexible labor supply: a welfare analysis of life-cycle funds. American Economic Review, 98(2): 297-303.

Greene, W. (2011) Econometric Analysis. Englewood Cliffe: Prentice-Hall.

Hoevenaars, R., Molenaar, R., Schotman, P., and Steenkamp, T. (2008) Strategic asset allocation with liabilities: beyond stocks and bonds. Journal of Economic Dynamics and Control, 32: 2930-2970.

Huberman, G., and Jiang, W. (2006) Offering versus choice in 401 (k) plans: equity exposure and number of funds. Journal of Finance, 61(2): 763-801.

Inkmann, J., and Michaelides, A. (2012) Can the life insurance market provide evidence for a bequest motive? Journal of Risk and Insurance, 79(3): 671-695.

Inkmann, J., Blake, D., and Shi, Z. (2014) Managing financially distressed pension plans in the interest of beneficiaries. Forthcoming in the Journal of Risk and Insurance.

Inkmann, J., Lopes, P., and Michaelides, A. (2011) How deep is the annuity market participation puzzle? Review of Financial Studies, 24(1): 279-319.

Iyengar, S., and Kamenica, E. (2010) Choice proliferation, simplicity seeking, and asset allocation. Journal of Public Economics, 94(7): 530-539.

Longstaff, F. A. (2010) The subprime credit crisis and contagion in financial markets. Journal of Financial Economics, 97(3): 436-450.

Maddala, G. S. (1983) Limited-Dependent and Qualitative Variables in Econometrics. Cambridge: Cambridge University Press.

Madrian, B., and Shea, D. (2001) The power of suggestion: inertia in 401 (k) participation and savings behavior. Quarterly Journal of Economics, 116(4): 1149-1187.

Mercer (2014) Mysuper market trends. Report, Mercer Investments.

Mitchell, O., and Utkus, S. (2004a) Lessons from behavioral finance for retirement plan design. In Mitchell, O., and Utkus, S. (ed), Pension Design and Structure: New Lessons from Behavioral Finance. Oxford: Oxford University Press, pp. 3-42.

Mitchell, O., and Utkus, S. (2004b) The role of company stock in defined contribution plans. In Mitchell, O., and Smetters, K. (ed), The Pension Challenge: Risk Transfers and Retirement Income Security. Oxford: Oxford University Press, pp. 33-70. 
Morin, R. A., and Suarez, A. F. (1983) Risk aversion revisited. Journal of Finance 38(4), 12011216.

Muir, D. (2012) Choice architecture and the locus of fiduciary obligations in defined contribution plans. Working Paper 1183, Ross School of Business.

Olson, R. (1978) Note on the uniqueness of the maximum likelihood estimator for the tobit model. Econometrica, 46(5): 1211-1215.

Papke, L. (2003) Individual financial decisions in retirement saving plans: the role of participant-direction. Journal of Public Economics, 88(1): 39-61.

Poterba, J., Rauh, J., Venti, S., and Wise, D. (2009) Lifecycle asset allocation strategies and the distribution of $401(\mathrm{k})$ retirement wealth. In Wise, D. (ed), Developments in the Economics of Aging. Chicago: University of Chicago Press, pp. 15-56.

Riley, W. B. Jr., and Chow, K. V. (1992) Asset allocation and individual risk aversion. Financial Analysts Journal, 48(6): 32-37.

Sethi-Iyengar, S., Huberman, G., and Jiang, W. (2004) How much choice is too much? Contributions to $401(\mathrm{k})$ retirement plans. In Mitchell, O. and Utkus, S. (eds), Pension Design and Structure: New Lessons from Behavioral Finance. Oxford: Oxford University Press, pp. 83-96.

Sharpe, W. F., and Tint, L. G. (1990) Liabilities - a new approach. Journal of Portfolio Management, 16(2): 5-10.

Thaler, R., and Sunstein, C. (2003) Libertarian paternalism. American Economic Review, 93(2): 175-179.

Van Binsbergen, J. H., and Brandt, M. W. (2009) Optimal asset allocation in asset liability management. Working paper, Stanford University.

Van Rooij, M., and Teppa, F. (2014) Personal traits and individual choices: taking action in economic and non-economic decisions. Journal of Economic Behavior \& Organzation, 100: $33-43$.

Vanguard (2009) How America saves 2009: A report on Vanguard 2008 defined contribution plan data. Report, The Vanguard Group, Inc.

Viceira, L. (2009) Life-cycle funds. In Lusardi, A. (ed), Overcoming the Saving Slump: How to Increase the Effectiveness of Financial Education and Saving Programs. Chicago: University of Chicago Press.

Welch, I., and Goyal, A. (2008) A comprehensive look at the empirical performance of equity premium prediction. Review of Financial Studies, 21(4): 1455-1508.

\section{Appendix A Econometric specification}

The dependent variables used in the regressions of this paper - the default share of risky assets and the share of plan assets invested in the default fund - are doublecensored at 0 and 1. Predictions from a linear regression model are not constrained to fall within this interval. Therefore we present maximum-likelihood (ML) estimates of two-limit tobit models throughout the paper. This appendix describes the log-likelihood function for this model and - more importantly - discusses estimation of APEs and their asymptotic standard errors.

For our purposes, the two-limit tobit model results from specifying a latent regression of the form $y_{i t}^{*}=x_{i t} \beta+u_{i t}$ with $u_{i t} \mid x_{i t} \sim N\left(0, \sigma_{u}^{2}\right)$. Instead of the latent variable $y_{i t}^{*}$, we observe the double-censored variable $y_{i t}=y_{i t}^{*} 1\left(0<y_{i t}^{*}<1\right)+1\left(y_{i t}^{*} \geq 1\right)$, where $1(\cdot)$ denotes the indicator function, which is unity if the argument is true and zero otherwise. The pooled two-limit tobit model treats repeated observations, $t=$ $1, \ldots, T_{i}$, of the same pension plan, $i=1, \ldots, N$, like additional cross-sectional observations. The log-likelihood function for this model is a straightforward extension of the 
corresponding function for the $T_{i}=1$ case derived by Maddala (1983), p.161

$$
\begin{aligned}
\log L(\theta)=\sum_{i=1}^{N} \sum_{t=1}^{T_{i}}\left[1\left(y_{i t}=0\right) \log \Phi\left(-x_{i t} a\right)+1\left(0<y_{i t}<1\right) .\right. \\
\left.\quad\left(\log g+\log \phi\left(y_{i t} g-x_{i t} a\right)\right)+1\left(y_{i t}=1\right) \log \Phi\left(x_{i t} a-g\right)\right],
\end{aligned}
$$

where we use the Olson (1978) parameter transformation, $\alpha=\beta / \sigma_{u}$ and $g=1 / \sigma_{u}$, and where $\theta=\left(a^{\prime}, g\right)^{\prime}$ and $\Phi(\cdot)$ and $\phi(\cdot)$ denote the cdf and pdf of the standard normal distribution, respectively.

Unlike the OLS estimator of the linear model, the ML tobit estimator of the slope coefficient $\beta_{k}$ of the $k$ th variable $x^{k}{ }_{i t}$ does not estimate the partial impact of $x^{k}{ }_{i t}$ on $y_{i t}$. For this reason, we present APEs throughout the paper. To derive these, denote the conditional expectation of the observed dependent variable as $\mu\left(x_{i t}, \theta\right) \equiv E\left[y_{i t} \mid x_{i t}\right]$, where (Maddala, 1983, p.161)

$\mu\left(x_{i t}, \theta\right)=x_{i t} \beta\left[\Phi\left(g-x_{i t} a\right)-\Phi\left(-x_{i t} a\right)\right]+\sigma_{u}\left[\phi\left(-x_{i t} a\right)-\phi\left(g-x_{i t} a\right)\right]+\Phi\left(x_{i t} a-g\right)$.

Then the estimated APE of a continuous variable $x^{k}{ }_{i t}$ on $E\left[y_{i t} \mid x_{i t}\right]$ is equal to the $k$ th element of the vector

$$
\widehat{A P E}=\left.\left(\sum_{i=1}^{N} T_{i}\right)^{-1} \sum_{i=1}^{N} \sum_{t=1}^{T_{i}} \frac{\partial \mu\left(x_{i t}, \theta\right)}{\partial x_{i t}}\right|_{\theta=\widehat{\theta}},
$$

where we derive $\frac{\partial \mu\left(x_{i t}, \theta\right)}{\partial x_{i t}}=\beta\left[\Phi\left(g-x_{i t} a\right)-\Phi\left(-x_{i t} a\right)\right]$ for the two-limit tobit model. Greene (2011, p. 699), shows that $\widehat{V}[\widehat{A P E}]=\widehat{G} \widehat{V}[\widehat{\theta}] \widehat{G}^{\prime}$ is an estimator of the asymptotic covariance matrix of $\widehat{A P E}$ where $\widehat{V}[\widehat{\theta}]$ is an estimator of the asymptotic covariance matrix of the ML estimator and

$$
\widehat{G}=\left.\left(\sum_{i=1}^{N} T_{i}\right)^{-1} \sum_{i=1}^{N} \sum_{t=1}^{T_{i}} \frac{\partial^{2} \mu\left(x_{i t}, \theta\right)}{\partial x_{i t} \partial \theta^{\prime}}\right|_{\theta=\widehat{\theta}} .
$$

We use the sandwich covariance estimator to obtain $\widehat{V}[\widehat{\theta}]$. 